\title{
Creative Game Design Training Requirements
}

\author{
Raudyah Md Tap ${ }^{\text {a, }}$, Nor Azan Mat Zin ${ }^{\text {a }}$, Hafiz Mohd Sarim ${ }^{\mathrm{a}}$ \\ ${ }^{a}$ Center for Software Technology and Management, Faculty of Information Science and Technology, Universiti Kebangsaan Malaysia, 43600 \\ Bangi, Selangor, Malaysia \\ Corresponding author: ${ }^{*}$ p94662@siswa.ukm.edu.my
}

\begin{abstract}
Current technological advances have replaced traditional games with digital games, which indicate the rapid expansion of digital or video games. Creativity and innovation are essential elements for designing successful games. However, many games produced in the market failed due to a lack of creativity. There is no specific method of training creativity for game courses taught at higher learning institutions. Game designers also have no specific tool to help them create innovative games. Therefore, a systematic approach to train creative game designing skills is needed. This study aimed to model the requirements for creativity training in game design. Specifically, the study's objectives are to identify creativity components for game design, develop a training model and validate it. The method used involved document analysis, interviews with game developers and game development educators, and the model's construction by mapping and validating the model using the expert review technique. Results found that intelligence, thinking style, motivation, personality, experience, game genre, environment, storyline, goals, rules, community, and task distribution are requirements for creative game design. These elements were mapped and categorized as the model components - the designer, knowledge, creativity training in the game design process, method, and technology support. The model validation result using the Inter-Rater Reliability (IRR) coefficient is $0.90(90 \%)$, indicating excellent reliability as approved by the experts. The creativity training model will be implemented either in software or conventional training modules for designing creative games.
\end{abstract}

Keywords - Creativity; creative thinking; training model; game design; playcentric method.

Manuscript received 31 Oct. 2019; revised 26 Nov. 2020; accepted 24 Dec. 2020. Date of publication 28 Feb. 2021. IJASEIT is licensed under a Creative Commons Attribution-Share Alike 4.0 International License.

\section{INTRODUCTION}

A game is a system where players engage in an artificial conflict for entertainment or educational purposes. Today, computer games are the most exciting form of entertainment among youths, children, and adults. Furthermore, technological advancement has a significant impact on mobile game applications and computer games. Many new games entered the market, and they are easily acquired. Thus, game designers experience a competitive environment. Game designers' tasks become more challenging as there are many new games on the market.

Furthermore, technology evolution is significant in influencing computer game development [1], [2]. Upgrades and enhancements to hardware make gaming better, and thus more large-scale games are developed. Computer game production started more than four decades ago by creating the earliest game called 'Spacewar' [3]. Two decades later, most computerized games were no longer produced just by any individual but by a small number of programmers [4].
The video game industry spearheads video game monetization, development, and marketing. This industry is a significant economic sector that provides thousands of wide-ranging employment opportunities globally [5]. According to Newzoo's Global Games Market Report [6], a market research firm that tracks trends and usage of esports, mobile, and video games, this year, gamers worldwide will likely spend around $\$ 138$ billion on games. This number correlates to an extra $\$ 16.2$ billion or a 13.3 percent increase year over year. The world is now seeing the advent of 2.5 billion gamers. Altogether, both groups are expected to drive an increase of $+9.6 \%$ year-on-year, based on projected spending of $\$ 152.1$ billion on games in 2019.

One of the most crucial phases of game development is the game design - a field that is far from limited. Hence, it is common to see game designers with diverse backgrounds in graphic design, creative writing, computer science, and programming. These designers take the creative lead and breathe life into the characters, gameplay, interface, dialogue, rules, environments, and stories of games. Hence, creative thinking and skills are essential assets for game designing, thus need to be taught to aspiring game designers. Therefore, 
this study's main objective is to propose a model of creativity training for game design.

\section{A. Technology and Computer Games}

Technological changes in Information and Communication Technology (ICT) have led mainly to the rapid development in various aspects [7]. Various industries such as education, medicine, defense, arts, and entertainment in computer games, use ICT. Hence, the production of many digital games on various platforms has increased. There have been studies on the effectiveness of games concerning IT advancement when applied in education to produce efficiency, effectiveness, and quality [8]. In any domain that uses computer games, the main emphasis is on the game's design, including creativity in the design process. It is challenging to create interactive and practical computer games [4]. Two essential elements to emphasize in computer games are graphics and creative sound; graphics rules and game engines control each graphic and sound [9]. Computer games' development involves computing, including computer graphics, artificial intelligence, human-computer interaction, security, distributed programming, simulation, and software engineering [10], [11]. The game design process needs a level of creativity rooted in game design and advanced science-based analogies. This process can be achieved using system discovery computation [12]. Therefore, computer games are evolving in line with technological advances.

\section{B. Creativity and Creative Skills}

Creativity and innovation are becoming increasingly crucial for the development of the 21st-century knowledge society. They contribute to economic prosperity as well as to social and individual wellbeing. They are essential factors for a more competitive and dynamic country. Education is central to fostering creative and innovative skills. Creativity and innovation can play essential roles in a knowledge society, as the fruitful interdisciplinary debate presented in this report demonstrates. Creativity is a skill for all; it is an ability that everyone can develop, thus, can be fostered or, likewise, inhibited. Educational actors have the power to unlock the creative and innovative potential of the young.

Creativity comes from the Latin word, 'Creo,' which means to create or build. Creativity is an abstract concept; researchers and scholars have put forward various definitions [13]. From a psychological perspective, creativity is the ability to produce new and valuable ideas or products. Creativity is a process that results in the creation of something new and beneficial [14]. Creativity is the process of formulating, reviewing, and evaluating hypotheses to solve a new problem [15].

A creative person is a product of his/her social environment, personality trait, and cognitive ability [16]. Nevertheless, this study defines creativity as a person's ability to produce or uniquely combine incredible ideas by thinking uniquely. Creativity is also defined as one's ability to apply one's experience to solve a problem without being bogged down by the rules. Therefore, effective problemsolving can be achieved when creativity-related skills, work motivation, and superior skills are combined. Today's increasingly complex social environment calls for critical skills to drive national development - one of which is undoubtedly creativity [17]. It is also one of the significant components of science and technology development [18].

The ability to think and act creatively becomes increasingly essential. Creative ideas had long existed before independence. Unfortunately, the present generation has lost the ability to think creatively and innovatively because of a lack of participation or interest. Nowadays, technology is ready-made and available, so the current generation only cares to consume and not create or design something original. Therefore, the coming generation should endeavor to be more creative and productive to survive this increasingly challenging world [19]. The country has started to focus on creativity as an essential element in education, especially in science [20]. The formation of scientific and technological ideas is through imagination. Thus, creativity in science and technology education refers to the promotion and strengthening of imagination in the context of science and technology [21].

Educators should know how to promote creative elements, including divergent thinking, the authenticity of student ideas, and encouraging students to become more creative [22]. Educators are responsible for providing a teaching and learning medium to train students to evaluate from various perspectives so that their learning is meaningful.

\section{Creativity in Game Design}

One study [10] posits that the process of game design is iterative and playcentric. Continuous game testing is to understand the player's need better. Playcentric approach is supported by [23], [24], who further explains the importance of the design element to process feedback from the player's game design experience. The two best game design practices are prototyping and playtesting, focusing on providing designers with a better understanding. The creative game design theory revolves around five principles [10]; (1) game designers are also gamers, (2) the crux of creative game design is to gain knowledge, (3) designers are also in-game science explorers (4), creative design computational models inspire automatic discovery systems, and (5) game design involves for-profit activities that are based on creative design knowledge.

One needs to foster creative thinking because it helps one generate ideas, improving and becoming more productive and effective. A creative one is also one who is curious and interested in pursuing knowledge. Creative skills contribute to game system designs by providing knowledge-oriented creativity support tools. There is a research gap in creative skills training in game design to create creative game designers. Although there are many creative and talented people in the game industry, creativity is not a given; it must be developed [25]. Hence this study analyses requirements in developing creativity for game designing.

\section{Dimensions of Creativity}

There are four specific dimensions of creativity; creative individuals, innovative products, creative processes, and creative environments [10], [26]. The creative individual is determined based on human behavior characteristics, including the ability to imagine, the freedom of thought, and the desire to try new things. A creative product refers to a 
physical or abstract object with a unique feature to distinguish it from other products. Moreover, the third dimension, the creative process, refers to the quest for creative ideas. Environments refer to the relationship between human and their situation and environmental factors that enable creative achievement.

Even if an individual does a creative process and no product is produced, he is still considered as creative [27]. The basic processes of creativity are originality, smoothness, flexibility, and paranormality [28]. Originality refers to the process of generating unique ideas. Smoothness refers to the ability to generate ideas in large quantities. Flexibility is the ability to express ideas from different perspectives and categories, and paranormality is widely able to think outside of the box and different from the norm [29], [30].

\section{The MAterial AND MethoD}

The methods used in this study are literature studies and interviews. Literature was reviewed and analyzed to identify components and creativity dimensions, creative and innovative thinking components, and related theories. Next, six-game developers from the gaming industry were interviewed on game design practices to identify game design skill training requirements. The interviews were conducted using the unstructured interview method - an informal interview containing random questions. An unstructured interview is an informal conversational, indepth, non-standardized, or ethnographic interview. This interview facilitates an open discussion between analysts and stakeholders to obtain qualitative data, which is particularly useful to develop a deep understanding of a specific issue within a particular community [31].

Data obtained are analyzed, and a conceptual model was then constructed based on the requirements obtained. InterRater Reliability (IRR) technique is used to validate the model using expert consensus and feedback. This IRR test obtains the agreement between ratters in the testing process [32]. The IRR gives a score of the level of consensus or agreement between the experts. The IRR is 1 (or 100\%) if everyone agrees and $0(0 \%)$ if everyone disagrees. Two academic experts and two gaming industry experts were the four experts selected for this study.

\section{RESULTS AND DISCUSSION}

\section{A. Creativity Design Model}

Nineteen elements are identified from the literature and interviews. The elements are then examined to see their relationship and possible categorization into distinct components for conceptual model construction. There are four main requirements of creativity for game design; designer, knowledge, skills, and technology components. The designer and knowledge components relate to each other, where knowledge is derived from several individual factors. Both these two components are inputs to creativity in game design. The designer component has four required elements towards generating creative thinking in game design (see Table I).

Table 1 shows the four designer components: intelligence, thinking style, motivation, and personality. These are elements of creativity theory [32] as well as game industry practices. The designer elements are essential in ensuring that the game is well-crafted. Table I summarizes the designer component.

TABLE I

DESIGNER COMPONENT

\begin{tabular}{|c|c|}
\hline Elements & Description \\
\hline Intelligence & $\begin{array}{l}\text { Three types: } \\
\text { - Synthetical intelligence (creative ability, } \\
\text { creativity, exploration), } \\
\text { - Analytical intelligence (ability to analyze, } \\
\text { control, and cognitive assessment) and } \\
\text { - practical intelligence (actions that allow } \\
\text { individuals to apply what they have learned). } \\
\text { Refer to individuals or groups in the process of } \\
\text { producing creativity. }\end{array}$ \\
\hline $\begin{array}{l}\text { Thinking } \\
\text { style }\end{array}$ & $\begin{array}{l}\text { - Divergent thinking is involved when dealing } \\
\text { with something that requires creative solutions. } \\
\text { - Always question the conventional things and } \\
\text { replace them with something new and think } \\
\text { creatively and critically outside the 'box.' }\end{array}$ \\
\hline Motivation & $\begin{array}{l}\text { - Action stimulation creates encouragement or } \\
\text { enthusiasm in order to achieve the purpose of the } \\
\text { activity with the group. } \\
\text { - The impetus that arises in or within the } \\
\text { individual that moves and directs his behavior. } \\
\text { - Two types: } \\
\text { - Intrinsic or personal motivation (the direction of } \\
\text { self-stimulation without external factor) } \\
\text { - Extrinsic Motivation. }\end{array}$ \\
\hline Personality & $\begin{array}{l}\text { Individuals who are open to criticism, } \\
\text { courageous, always positive regardless of any } \\
\text { reprimand, visionary, open-minded, possessive, } \\
\text { and daring to come up with new ideas will make } \\
\text { a good designer. }\end{array}$ \\
\hline
\end{tabular}

The second requirement for a creative training model of game design is knowledge. Knowledge is a significant component to enable creative skills. The knowledge component has four elements. The experience and environment and game genre and storyline are the sources of knowledge to game design. Game designers need to seek knowledge in designing games continuously. Existing knowledge of the design can be used to realize a familiar and well-understood gaming experience. However, creative game designs demand continuous design knowledge obtained from various sources [33].

Knowledge refers to design knowledge that includes design patterns to be used, game ideas, how games are played, and how the design creates a gaming experience against users. These four elements of the knowledge component are essential in generating continuous game design knowledge. See Table 2 for the knowledge component summary. Knowledge requires creativity; hence, game design's creativity training process requires three main elements; skills, methods, and technologies (see Table 3).

A software product design requires a fair process and a systematic method guide to achieving success in software development [34]. Creative skills consist of six elements derived from creative thinking components [35] and game industry practices; correlate, synthesize, generate ideas, imitations, inventions, and game analysis. The process refers to the time and skills required in acquiring creativity for a 
thing [36]. Therefore, in implementing an effective creative process in designing a game, six elements of the skills are required. Table III describes these six elements.

TABLE II

KNOWLEDGE COMPONENT

\begin{tabular}{ll}
\hline Elements & \multicolumn{1}{c}{ Description } \\
\hline Storyline & - Storyline production for game design \\
& - Get the character in the game \\
& - Examples: comics, cartoon, storytelling, \\
storyboard, and script generation \\
Game Genre & - Current trends in game design \\
& - User requirements and needs \\
Environment & - User interest \\
& Environmental factors that help in generating \\
& creativity - safe, consistent, supportive, \\
& harmonious, and competitive \\
& - Technological and group environment \\
& Bureaucratic environments, strictly following \\
& rules and laws will limit and discourage creative \\
& activities \\
Experience & The individual experience of the group or others' \\
& experience is needed in the process of generating \\
& ideas in the creative design phase of the game \\
& - The reality of one's own life, the memories of \\
& memory or the fantasy and the illusions of a \\
& person can be fair game ideas
\end{tabular}

TABLE III

CREATIVE SKILLS

\begin{tabular}{|c|c|}
\hline Elements & Description \\
\hline Correlate & $\begin{array}{l}\text { - Refers to the ability to link one thing to another or } \\
\text { to associate new ideas with an existing idea } \\
\text { - It is linking existing experience with new } \\
\text { experiences } \\
\text { - Make an affinity for finding a structure or } \\
\text { relationship pattern. This skill is used to create } \\
\text { inferences, predict, hypothesize, conclude, and } \\
\text { manipulate }\end{array}$ \\
\hline Synthesize & $\begin{array}{l}\text { - Synthesizing is the process of unifying various } \\
\text { elements, divisions, materials, and minds } \\
\text { - Combine different ideas, elements, items, and things } \\
\text { to create a comprehensive overview of statements, } \\
\text { essays, paintings, and artefacts } \\
\text { This skill is also used to produce communication } \\
\text { forms such as paintings, storyboards, maps, diagrams, } \\
\text { poems, and reports. }\end{array}$ \\
\hline $\begin{array}{l}\text { Generate } \\
\text { ideas }\end{array}$ & $\begin{array}{l}\text { - Creative thinking contains the developmental } \\
\text { features of ideas that can provide a variety of new } \\
\text { alternatives } \\
\text { - Discuss and find ideas in teams } \\
\text { - It is the capabilities or the process of exposing new } \\
\text { ideas in groups or individuals } \\
\text { - Be sensitive to things around } \\
\text { - Make observations to identify problems, errors, and } \\
\text { weaknesses } \\
\text { - Practice the creative process to generate new ideas } \\
\text { continuously } \\
\text { - Generate many ideas spontaneously with something. } \\
\text { This skill is used when looking for new ideas and } \\
\text { looking for alternatives. }\end{array}$ \\
\hline Imitation & $\begin{array}{l}\text { - Imitating process from other game designs. } \\
\text { - Looking at successful products } \\
\text { - Modify existing games } \\
\text { - Repeat or mimic the process by using original ideas } \\
\text { - Encouragement to imitate something that is in } \\
\text { others. } \\
\text { - Occurs when there is a previously successful game } \\
\text { design interest, attention, and result }\end{array}$ \\
\hline $\begin{array}{l}\text { Game } \\
\text { analysis }\end{array}$ & $\begin{array}{l}\text { - Criticize and analyze existing games } \\
\text { - Make a reflection on the game's journals }\end{array}$ \\
\hline
\end{tabular}

\begin{tabular}{lc}
\hline Elements & \multicolumn{1}{c}{ Description } \\
\hline Invent & $\begin{array}{l}\text { P Produce something new or modify something } \\
\text { already present in real or abstract form }\end{array}$ \\
\hline
\end{tabular}

Method refers to a particular procedure used to achieve something. The method identified from industry practices and literature review is play centric. Playcentric is an approach to design an innovative gaming experience that can provide an excellent emotional experience to players [37]. Playcentric also is an approach to design an exciting, creative, and innovative game experience. Playcentric is a repeat process from designing, testing, and evaluating the design of the game. The fundamental goal of a playcentric approach is to build sufficient skills and understanding to produce creative and quality designs.

Also, technology is required to assist the activities involved in training creative skills in game design. The technical support has four elements derived from the activity theory [38]; goals, community, distribution of tasks and rules. Technology is needed for today's students learning. Designing a valuable commercial product is fraught with challenges, including problems in the design process, which could be solved with scientific and creative thinking [39], [40]. Therefore, to ensure effective technology use, four supporting elements are needed to train creative skills in game design. Table IV describes the four elements.

\begin{tabular}{|c|c|}
\hline \multicolumn{2}{|r|}{$\begin{array}{l}\text { TABLE IV } \\
\text { TECHNOLOGY }\end{array}$} \\
\hline Elements & Description \\
\hline Goal & $\begin{array}{l}\text { - The purpose or output specified in the activity } \\
\text { - Objectives or tensions to achieve or solve an } \\
\text { activity that induces individuals and } \\
\text { communities to participate in activities }\end{array}$ \\
\hline Community & $\begin{array}{l}\text { - Individual groups are undergoing similar } \\
\text { activities in the process of learning } \\
\text { activities/ideas generating activities/designing } \\
\text { games. } \\
\text { - Communities share the same object, location, } \\
\text { and the same time } \\
\text { - The same object, location and time factors are } \\
\text { to determine the determination of the activity, } \\
\text { to determine the study participants when the } \\
\text { researcher conducts the analysis }\end{array}$ \\
\hline $\begin{array}{l}\text { Distribution } \\
\text { of tasks }\end{array}$ & $\begin{array}{l}\text { - Represents the various responsibilities of } \\
\text { individuals involved in an activity } \\
\text { - Sharing of tasks within the community }\end{array}$ \\
\hline Rules & $\begin{array}{l}\text { - Rules can be anything explicit or implicit } \\
\text { about policies, rules and guidelines in an } \\
\text { activity that is carried out or processed }\end{array}$ \\
\hline
\end{tabular}

All components and elements discussed above are essential for developing and training creative skills in game design. To summarize, a conceptual creativity training model for the game design was developed, encompassing all these requirements.

\section{B. Creativity Training Model for Game Design}

Figure 1 shows the proposed model, which has four main components that are essential for creativity skills training in game design. The input is the designer and knowledge components. The designer component elements are intelligence, thinking style, motivation, and personality, as 
shown in Table I. The knowledge component elements are experience, game genre, environment, and storyline, as indicated in Table II. The next two requirements are the process of creativity in game design training, which consists of three main components, i.e., (creative) skill process, method, and technology support. There are six main elements in the skill process - correlate, synthesize, imitations, game analysis, generate ideas, and invent (Table III).

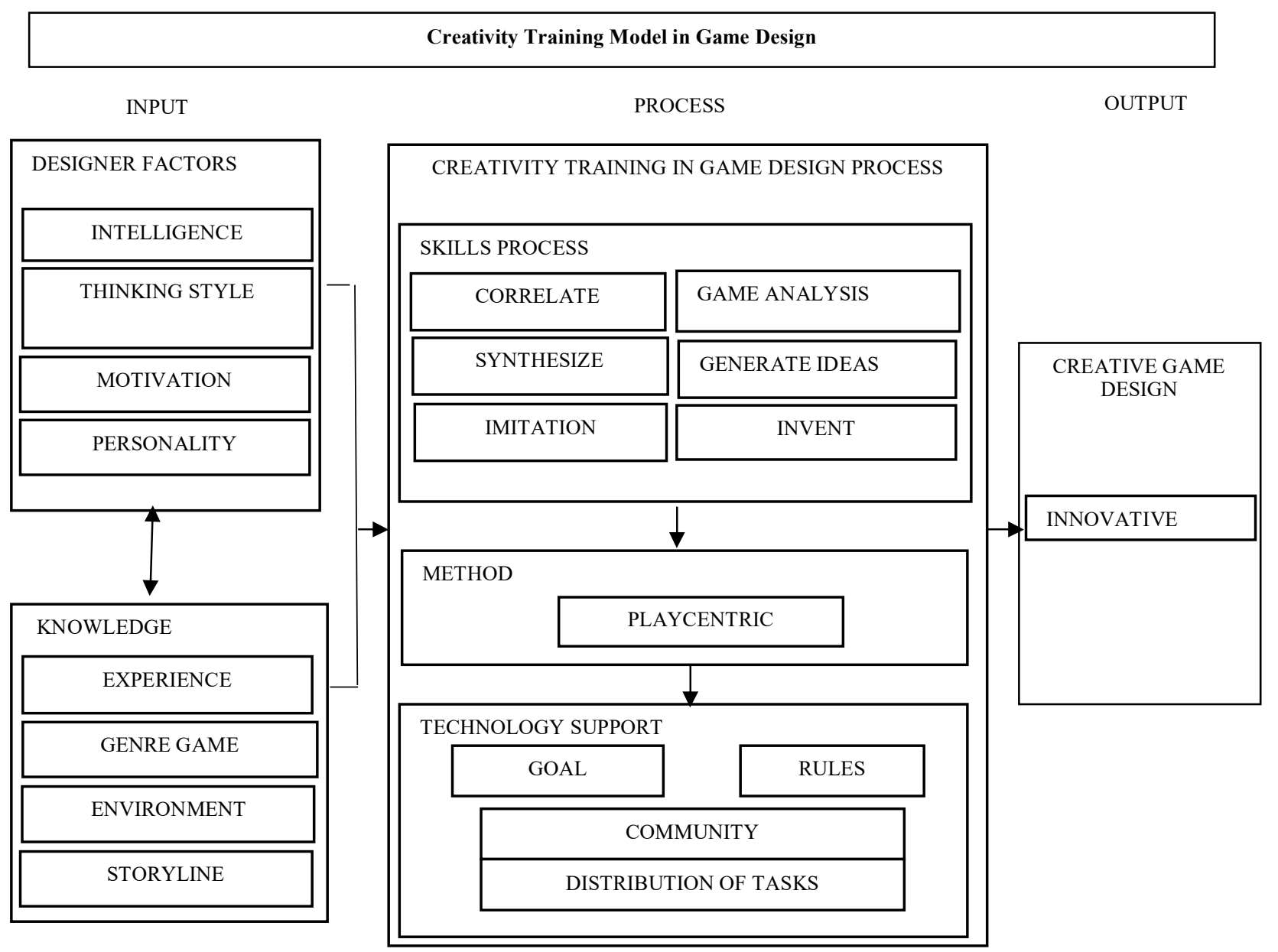

Fig. 1 Creativity training model for game design

Playcentric is a method used in game design. Playcentric is a process of design and iteration that includes generating ideas, formalizing ideas, testing ideas, and evaluating ideas. This method can also be applied to game design and is essential to designing an emotionally engaging and innovative game experience.

Finally, there are four elements of technology support: goals, rules, communities, and task distribution. All the components in this model are the results from requirement analysis, drawn from the dimensions of creativity, creative and innovative thinking components, and the theory of creativity and activity theory.

Based on the input, as a result of the processes, creative and innovative designs are created as output. Innovative is the ability to think freshly through certain stages and conditions. Besides, innovation refers to the creation of new products or better services. Also innovative is a process thinking to produce something new in the market that would change the similarities between demand and withdrawal.

\section{Model Validation Result}

The IRR coefficient used is the percentage approval agreement coefficient, the resulting IRR approval for the model is $0.90(90 \%)$, indicating excellent reliability. Various experts have agreed that a consent percentage of $75 \%-90 \%$ is an acceptable level of agreement [41]. According to the expert's agreement in game design, the analysis of the components is presented in Table V.

\section{Expert Feedback}

Furthermore, the experts' feedback was collated and assessed to improve the creativity training model further. This feedback will be used to improve the model in future work. Table 6 presents the feedback on some of the model element descriptions based on the experts' experience and perspective. The results show that 11 of the 19 components of the creativity training model for game design requires improved element description. 


\begin{tabular}{|c|c|c|c|c|c|c|c|c|c|c|c|c|c|}
\hline No & Components & 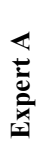 & 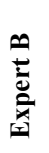 & 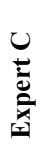 & 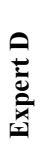 & 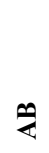 & $\underset{\mho}{\mho}$ & 2 & $\bigcup_{\infty}$ & คิ & 已 & & 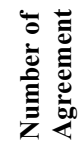 \\
\hline 1 & Intelligence & 1 & 1 & 1 & 1 & 1 & 1 & 1 & 1 & 1 & 1 & $6 / 6$ & 6 \\
\hline 2 & Thinking style & 1 & 1 & 1 & 1 & 1 & 1 & 1 & 1 & 1 & 1 & $6 / 6$ & 6 \\
\hline 3 & Motivation & 1 & 1 & 1 & 1 & 1 & 1 & 1 & 1 & 1 & 1 & $6 / 6$ & 6 \\
\hline 4 & Personality & 1 & 1 & 1 & 1 & 1 & 1 & 1 & 1 & 1 & 1 & $6 / 6$ & 6 \\
\hline 5 & Experience & 1 & 1 & 1 & 1 & 1 & 1 & 1 & 1 & 1 & 1 & $6 / 6$ & 6 \\
\hline 6 & Environment & 1 & 1 & 1 & 1 & 1 & 1 & 1 & 1 & 1 & 1 & $6 / 6$ & 6 \\
\hline 7 & Game Genre & 1 & 1 & 1 & 1 & 1 & 1 & 1 & 1 & 1 & 1 & $6 / 6$ & 6 \\
\hline 8 & Storyline & 1 & 1 & 1 & 1 & 1 & 1 & 1 & 1 & 1 & 1 & $6 / 6$ & 6 \\
\hline 9 & Correlate & 1 & 1 & 1 & 1 & 1 & 1 & 1 & 1 & 1 & 1 & $6 / 6$ & 6 \\
\hline 10 & Imitation & 1 & 1 & 0 & 1 & 1 & 0 & 1 & 0 & 1 & 0 & $3 / 6$ & 3 \\
\hline 11 & Game analysis & 1 & 1 & 1 & 1 & 1 & 1 & 1 & 1 & 1 & 1 & $6 / 6$ & 6 \\
\hline 12 & Synthesis & 1 & 0 & 1 & 1 & 0 & 1 & 1 & 0 & 0 & 1 & $3 / 6$ & 3 \\
\hline 13 & Generate ideas & 1 & 1 & 1 & 1 & 1 & 1 & 1 & 1 & 1 & 1 & $6 / 6$ & 6 \\
\hline 14 & Invent & 1 & 1 & 1 & 1 & 1 & 1 & 1 & 1 & 1 & 1 & $6 / 6$ & 6 \\
\hline 15 & Play centric & 1 & 1 & 1 & 1 & 1 & 1 & 1 & 1 & 1 & 1 & $6 / 6$ & 6 \\
\hline 16 & Community & 1 & 1 & 1 & 1 & 1 & 1 & 1 & 1 & 1 & 1 & $6 / 6$ & 6 \\
\hline 17 & Distribution of tasks & 1 & 1 & 1 & 1 & 1 & 1 & 1 & 1 & 1 & 1 & $6 / 6$ & 6 \\
\hline 18 & Rules & 1 & 1 & 1 & 1 & 1 & 1 & 1 & 1 & 1 & 1 & $6 / 6$ & 6 \\
\hline 19 & Goal & 1 & 1 & 1 & 1 & 1 & 1 & 1 & 1 & 1 & 1 & $6 / 6$ & 6 \\
\hline & & & & & & & & & & & \multirow{2}{*}{\multicolumn{2}{|c|}{ Total: }} & 108 \\
\hline & & & & & & & & & & & & & 0.9 \\
\hline & & & & & & & & & \multicolumn{4}{|c|}{ Inter-Rater Reliability (Mean): } & $90 \%$ \\
\hline
\end{tabular}

TABLE VI

EXPERT FEEDBACK

Component/elements

1. Designer

2.Thinking style

3. Personality

4. Experience

5. Environment

6. Genre of the game

7. Storyline

8. Correlate

9. Imitation

10. synthesis

11. Technology

\section{Description}

- Literature study on metacognitive which can be attributed to a designer's way of thinking

- Literary studies of the ability of ideological thinking style-according to Islamic perspective on creative thinking

Component description:

- Group discussions to help in the thinking process of the design, to be developed and assured by all experts

Component description:

- Accepting others' ideas/opinions

- Cultivating that opinion until it becomes a new idea

Component description:

- The result of the previous successful design encourages improvement for new thinking

- Failure in design experience also drives better design changes

- Experience gained from other media work such as writing novels, scripts, or video captions

- Requires alpha testing to get feedback from the user experience

Component description:

- A relaxed and mood-filled environment of mood boards or references from other games to inspire game designers

- A sensitive environment with current issues

Component description:

- Designers need to know and study the types of games the users are interested in in the era of circulation

Component description:

- The storyline and character creation based on the theme and background one wants to highlight

- Scripts are required to generate exciting storylines

- The characters need to be designed to fit the game storyline

Component description:

- The process of reviewing the game trend from the beginning until now

Component description:

- Take the existing concept and add other ideas that are better in terms of games, missions, game controls

Component description:

- The storyboarding process of the session discussion

- The term technology may be confusing because technology means the use of technical tools; therefore, we propose 'supporting technology' to replace 'technology.'

- Additional literature studies on Engestrom's theoretical activity. 


\section{CONCLUSION}

The input requirements for training creativity in-game designs are the designer and knowledge components. The creativity training process in game design has three main components - skill, method, and technology. All components and elements of this model are requirements derived from game industry practices, theoretical components of creativity, the dimension of creativity, creative thinking, and innovative components, as well as creativity and activity theory. The model can be used to guide teaching and training creativity for designing a game. It can also act as a guide in training creative thinking for students, either through implementation in tools or training module, which will be part of the future work.

\section{ACKNOWLEDGMENT}

The authors acknowledge UKM for funding the research through grants DCP-2017-007/02 and PP-FTSM-2019. We also acknowledge the help provided by Metro Polytechnic Kuala Lumpur, Polytechnic and Community College Department, and the HLP Federal Training Specialist Scholarship provided by the Ministry of Higher Education Malaysia.

\section{REFERENCES}

[1] Ismail, Marina, et al. "Measuring usability of educational computer games based on the user success rate." 2011 International Symposium on Humanities, Science and Engineering Research. IEEE, 2011

[2] Qian, Meihua, and Karen R. Clark. "Game-based Learning and 21st century skills: A review of recent research." Computers in Human Behavior 63 (2016): 50-58.

[3] Anderson, Craig A., et al. "Media violence and other aggression risk factors in seven nations." Personality and Social Psychology Bulletin 43.7 (2017): 986-998

[4] Coyne, Sarah M., et al. "Violent video games, externalizing behavior, and prosocial behavior: A five-year longitudinal study during adolescence." Developmental psychology 54.10 (2018): 1868.

[5] Cardoso, Tiago, Joao Sousa, and Jose Barata. "Digital Games' Development Model.” EAI Endorsed Transactions on Serious Games 4.12 (2017).

[6] Li, Xi, Mengze Shi, and Xin Shane Wang. "Video mining: Measuring visual information using automatic methods." International Journal of Research in Marketing 36.2 (2019): 216-231.

[7] Gennari, Rosella, et al. "Children's emotions and quality of products in participatory game design." International Journal of HumanComputer Studies 101 (2017): 45-61.

[8] Nunez, Leonor A. Espinoza. "Development Serious Games Using Agile Methods. Test Case: Values and Attitudinal Skills." Telematics and Computing: 7th International Congress, WITCOM 2018, Mazatlán, Mexico, November 5-9, 2018, Proceedings. Vol. 944. Springer, 2018.

[9] Qian, Meihua, and Karen R. Clark. "Game-based Learning and 21st century skills: A review of recent research." Computers in Human Behavior 63 (2016): 50-58.

[10] Smith, Adam M., and Michael Mateas. "Knowledge-level Creativity in Game Design." ICCC. 2011.

[11] Ab Majid, Mohammad Rusdi Bin, and Zawawi Ismail. "Kreativiti Pengajaran Guru Bahasa Arab di Malaysia." JuPiDi: Jurnal Kepimpinan Pendidikan 4.4 (2017): 27-38.

[12] Mi, Shuaishuai, Hualin Bi, and Shanshan Lu. "Trends and Foundations of Creativity Research in Education: A Method Based on Text Mining." Creativity Research Journal (2020): 1-13.

[13] Ariffin, Siti Rahayah, et al. "Validity and reliability of the Malaysian creativity and innovation instrument (MyCrIn) using the Rasch measurement model." Proceedings of the 10th WSEAS international conference on E-Activities. World Scientific and Engineering Academy and Society (WSEAS), 2011.
[14] Sarkam, Saida Farhanah, et al. "Ihsan, Innovation and Creativity in Students' Product Innovation: The Case of Innovation Show Event at UiTM Pahang." International Journal of Academic Research in Business and Social Sciences 8.2 (2018).

[15] James, Molly A. "Managing the classroom for creativity." Creative Education 6.10 (2015): 1032.

[16] Tap, Raudyah Md, Nor Azan Mat Zin, and Hafiz Mohd Sarim. "Requirements For Creative Skills Development In Game Design." 2019 International Conference on Electrical Engineering and Informatics (ICEEI). IEEE, 2019.

[17] Amabile, Teresa M. "Educating leaders who make a difference in the world." Perspectives on Psychological Science 14.1 (2019): 7-11.

[18] Ott, Michela, and Francesca Pozzi. "Digital games as creativity enablers for children." Behaviour \& Information Technology 31.10 (2012): 1011-1019.

[19] Park, Jong-Won. "Developing the format and samples of teaching materials for scientific creativity in the ordinary science curriculumIncluding teachers' practice and reflection." Journal of the Korean Association for Science Education 32.3 (2012): 446-466.

[20] Chumo, Caroline Chelang'at. "Effects of practical investigation on scientific creativity amongs secondary schools biology students in Kerincho District, Kenya." Journal of Education and Practice 5.8 (2014): 43-51.

[21] Matthews, Elizabeth, Geoffrey Matthews, and Juan E. Gilbert. "A Framework for the Assessment of Enjoyment in Video Games." International Conference on Human-Computer Interaction. Springer, Cham, 2018.

[22] Walk, Wolfgang, Daniel Gorlich, and Mark Barrett. "Design, dynamics, experience (DDE): an advancement of the MDA framework for game design." Game Dynamics. Springer, Cham, 2017. 27-45.

[23] Thominet, Luke. "How to be open: User experience and technical communication in an emerging game development methodology." Communication Design Quarterly Review 6.2 (2018): 70-82.

[24] Torsi, Silvia, et al. "Eudaimonia and Behavior Change: Incorporating negative feelings into Game Design elements." Proceedings of the 6th EAI International Conference on Smart Objects and Technologies for Social Good. 2020.

[25] Romero, Margarida, Alexandre Lepage, and Benjamin Lille. "Computational thinking development through creative programming in higher education." International Journal of Educational Technology in Higher Education 14.1 (2017): 42.

[26] Maldonato, Mauro, Silvia Dell'Orco, and Anna Esposito. "The emergence of creativity." World Futures 72.7-8 (2016): 319-326.

[27] Singh, Umed, and Jagdish Kumar. "Personality and motivational correlates of creativity." Indian Journal of Health \& Wellbeing 8.12 (2017).

[28] Abdulla, Ahmed M., and Bonnie Cramond. "After six decades of systematic study of creativity: what do teachers need to know about what it is and how it is measured?." Roeper Review 39.1 (2017): 923 .

[29] Lince, R. (2016). Creative thinking ability to increase student mathematical of junior high school by applying models numbered heads together. Journal of Education and Practice, 7(6), 206-212.

[30] Gaither, Sarah E., Samantha P. Fan, and Katherine D. Kinzler. "Thinking about multiple identities boosts children's flexible thinking." Developmental Science 23.1 (2020): e0012871.

[31] Kausel, E. E., Culbertson, S. S., \& Madrid, H. P. (2016) Overconfidence in personnel selection: When and why unstructured interview information can hurt hiring decisions. Organisational Behavior and Human Decision Processes, 137, 27-44.

[32] Eagan, Brendan R., et al. "Can we rely on IRR? Testing the assumptions of inter-rater reliability." International Conference on Computer Supported Collaborative Learning. 2017.

[33] Rasul, M. S., Waheeda Ramli, N. F. \& Abd Rauf, R. A. (2013) Pembentukan karektor pelajar kreatif mengikut teori sternberg: Suatu analisis kandungan dan pembangunan kerangka konseptual. Jurnal Teknologi (Sciences and Engineering) 63(1): 7-15.

[34] Burnett, Margaret, et al. "Toward Theory-Based End-User Software Engineering." New Perspectives in End-User Development. Springer, Cham, 2017. 231-268.

[35] World Health Organization. (2015). Trends in maternal mortality: 1990-2015: estimates from WHO, UNICEF, UNFPA, World Bank Group and the United Nations Population Division. World Health Organization. 
[36] Roman-Calderon, Juan Pablo, et al. "Creativity and job tension in experiential learning." 2018 IEEE Frontiers in Education Conference (FIE). IEEE, 2018.

[37] Rosa, Aaron B., and John A. Sweeney. "Your Move: Lessons Learned at The Interstices of Design, Gaming, And Futures." Journal of Futures Studies 23.4 (2019): 137-42.

[38] Navarrete, Cesar C. "Creative thinking in digital game design and development: A case study." Computers \& Education 69 (2013): $320-331$.
[39] Rasul, Mohamad Sattar, et al. "Impact of integrated stem smart communities' program on students' scientific creativity." Journal of Engineering Science and Technology 13 (2018): 80-89.

[40] Afanasyeva, Ekaterina. "Scientific creativity and diversity of physical work environment: framework development." (2014).

[41] Belotto, Michael J. "Data analysis methods for qualitative research: Managing the challenges of coding, interrater reliability, and thematic analysis." The Qualitative Report 23.11 (2018): 2622-2633. 